\title{
BIOLOGICAL AND MOLECULAR CHARACTERIZATION OF STREPTOCOCCUS CRISTA STRAINS ISOLATED FROM HUMAN DENTAL BIOFILM BY MEANS OF ARBITRARY PRIMERS - PCR (AP-PCR)
}

\author{
Michelle Angelini ${ }^{1}$; Wanderley Dias da Silveira ${ }^{1}$; Tatiana Amabile de Campos ${ }^{1}$; Silvana Cai ${ }^{2}$; \\ Antonio Fernando Pestana de Castro ${ }^{2 *}$
}

${ }^{1}$ Departamento de Microbiologia e Imunologia, Instituto de Biologia, Universidade Estadual de Campinas, Campinas, SP, Brasil; ${ }^{2}$ Instituto de Ciências Biomédicas, Departamento de Microbiologia, Universidade de São Paulo, São Paulo, SP, Brasil

Submitted: June 29, 2005; Returned to authors for corrections: October 06, 2005; Approved: March 15, 2006

\begin{abstract}
Streptococcus ssp are important components of the dental biofilm and Streptococcus crista is considered to be an interesting model of bacterial interactions taking place in this biofilm. In the present work, S. crista strains were isolated from the dental biofilm of Brazilian individuals and studied with respect to their biological characteristics and their molecular profile by means of AP-PCR techniques, using the RR2, 434, OPR2, OPR8, and OPR 13 primers. Results allowed us to build a similarity dendrogram. Analysis of the similarity dendrogram allowed the separation of the studied strains into similarity groups. All isolates presented fibril tufts by Transmission Electron Microscopy (TEM). These isolates were able to bind to salivary amylase and to adhere to mouth epithelial cells. Some strains displaying fibril tufts and positive adherence were not able to co-aggregate with Fusobacterium nucleatum, suggesting that different adhesin groups are present in these strains.
\end{abstract}

Key words: biological characterization, molecular characterization, dendrogram analysis, biofilm

\section{INTRODUCTION}

The human oral cavity is considered to be the ecological niche with the widest biodiversity known to date. Approximately 700 species responsible for the formation of a biofilm on the dental surface can be found there (29). It is believed that the physical nature of the dental biofilm should facilitate the exchange of signals among the bacterial cells present in the oral cavity (45). The dental plaque is a microbial biofilm formed by organisms tightly bound to each other and to the solid substratum by means of an exopolymer matrix, in which the microorganisms are embedded. It is known that such microorganisms are involved in the etiology of the most common diseases of the oral cavity (36). Also, the presence of salivary proteins and bacterial cellular debris should help the adhesion of these bacteria to the enamel (33).
Among the bacterial species present in the dental biofilm, the Streptococcus mitis group $(17,32)$ is considered to be important for its formation. Streptococcus crista is a subspecies belonging to the $S$. mitis group $(10,13,15)$, and its biochemical characterization is considered to be difficult because of the phenotypic variation exhibited by individuals of the same species (30,31). S. crista are a Gram positive cocci that cannot produce catalase; hydrolyze arginine; or decompose manitol, sorbitol, inulin, and raffinose. They grow in sculine bile agar, can degrade threalose and lactose, bind to salivary amylase, and present a hemolysis $(3,9,43,44)$.

Salivary amylase is able to specifically bind to several species of oral streptococci. The amylase-binding capacity of these bacteria is used to differentiate between groups of oral streptococci $(9,19,37)$. Streptococcus mitis, Streptococcus gordonii, Streptococcus salivarious, Streptococcus anginous,

*Corresponding Author. Mailing address: Instituto de Ciências Biomédicas, Departamento de Microbiologia, Universidade de São Paulo, Cidade Universitária. 05508-900, São Paulo, SP, Brasil. Tel.: (+5511) 3091-7259, Fax: (+5511) 3091-7354. E-mail: apestana@icb.usp.br 
and $S$. crista are bacterial species that are able to bind to this amylase $(9,19,37,38)$. Moreover, the binding-amylase capacity is related to the oral bacterial colonization ability and biofilm formation $(4,16,39)$.

Bacterial adherence to surfaces is critical to their survival in the human oral cavity and has been associated with the formation of the human oral biofilm (4), being Streptococci the major components of this film (16). Bacterial cells express multiple cell-surface adhesins that are responsible for their ability to adhere to various other proteins, including salivary and serous proteins, as well as to epithelial cells and other bacterial cells (16).

On the surface of the human dental biofilm it is possible to find corncob structures that correspond to the specific formation of bacterial co-aggregation consisting of a central rod-shaped or filamentous bacterium surrounded by several other bound streptococci. These co-aggregates are highly ordered structures and usually consist of the gram positive pair Corynebacterium matruchotii- S. crista or the gram negative-gram positive pair Fusobacterium nucleatum- S. crista, with C. matruchotii and F. nucleatum being responsible for the central core. The binding capacity between $S$. crista and the other bacterial cells is due to a polar fibril tuft present on the surface of $S$. crista $(6,7,13,22,23,28)$.

Molecular characterization methods have been proposed in order to overcome the phenotypic variation displayed by $S$. crista (30,31). In 1999, Rudney and Larson (32) proposed the use of a technique known as arbitrary primers-PCR (AP-PCR), with primers designated RR2 and 434, as a simple, rapid, and low-cost technique to characterize this bacterium.

The purpose of this work was to study $S$. crista isolates obtained from the dental biofilm of individuals from the state of São Paulo, Brazil, with regard to their biological characteristics and molecular profiles, by means of the AP-PCR technique, as described by Rudney and Larson (32), and by using the OPR2, OPR8, and OPR13 primers, as described by Williams et al. (43). Our aim was to differentiate isolates from standard strains and from strains described by other groups.

\section{MATERIALS AND METHODS}

\section{Studied strains}

Bacterial growth was obtained from the mouth biofilm of 12 individuals (patients of the Dental Clinic of the São Francisco University, Bragança Paulista, SP), by using the method described by Lancy et al. (22), Correia et al. (6), and Mouton et al. (28). Strains of S. crista (CR3, CR311, and CC5AWT) (13) and Streptococcus parasanguis (PSH1a and PSH1b) (obtained from the Microbiology Dept. of the Dental School of the Pennsylvania State University, USA); Streptococcus sanguis, S. mitis, Streptococccus oralis, and S. gordonii (Microbiology Dept., ICB, University of São Paulo, Brazil); Streptococcus suis
2 and Streptococcus suis 527 (Veterinary Medicine School of Saint-Hyacinthe of Montreal University, Canada); and F. nucleatum (ATCC 10953) were used as controls.

\section{Biochemical identification of the isolates}

Biochemical tests for the mouth-isolated bacteria were accomplished as described by Beighton et al. (2,3), from cultures grown in rich liquid medium (Brain Heart Infusion - Difco). Acid production from mannitol, sorbitol, inulin, raffinose, lactose, and threalose; aesculin and arginine hydrolysis; as well as $\mathrm{H}_{2} \mathrm{O}_{2}$ production were determined as described by Beighton et al. $(2,3)$. Carbohydrate fermentation reactions were determined in basic medium cosisting of Purple Broth Base (Difco) (24g) and thioglycollate medium in the absence of dextrose or an indicator (Difco) (12g), with carbohydrates added to a concentration of $0.5 \%$ before autoclaving.

The amylase salivary test was performed as described by Douglas et al. (9), in order to eliminate those isolates that were not able to bind to this enzyme and thus could not be $S$. crista. Bacteria grown in the brain heart infusion broth (Difco) $(20 \mathrm{~mL})$ overnight at $37^{\circ} \mathrm{C}$ was harvested by centrifugation, washed once in 50mM phosphate buffer (pH6.5), and suspended in whole unstimulated saliva $(50 \mu \mathrm{L})$ previously colleted on ice and cleared by centrifugation at $4^{\circ} \mathrm{C}$ for $10 \mathrm{~min}$. at $20,000 \mathrm{Xg}$. The suspension was incubated at room temperature for $30 \mathrm{~min}$., and the bacteria was sedimented by centrifugation at $10,000 \mathrm{X} \mathrm{g}$ for $5 \mathrm{~min}$. at $4^{\circ} \mathrm{C}$. Samples $(10 \mu \mathrm{L})$ of the supernatant were assayed for amylase activity by diffusion from a $3.5 \mathrm{~mm}$ - diameter well punched in a starch agarose gel. The gel consisted of $1 \%$ agarose and $1 \%$ soluble starch (Merck) in $50 \mathrm{mM}$ tris-hydrochloride buffer (pH7.5). The gel was poured on a glass plate to a thickness of approximately $2 \mathrm{~mm}$. After incubation for 3 to $18 \mathrm{~h}$ at $37^{\circ} \mathrm{C}$ in a humid chamber, starch hydrolysis was visualized by staining the gel with lugol iodine. Wells showing no enzymatic activity or significantly reduced enzymatic activity were scored as positive, while wells showing a zone of starch hydrolysis identical to that seen with a control saliva sample were scored as negative.

Positive colonies were further confirmed by using the Vitek (bioMerieux) kit and the BBL Crystal (Becton Dickinson) kit.

\section{Genomic DNA extraction}

Bacterial genomic DNA was extracted as described by Ausubel et al. (1) and quantified as described by Sambrook et al. (34).

\section{AP-PCR and RAPD assay}

The AP-PCR assay was acomplished as described by Menard and Mouton (27), with the modifications proposed by Rudney and Larson (32), using the RR2 (5'-AAG AGA GGAG CTA GCT CTT CTT GGA-3') and 434 (5'-GCA CAA CAG TTC CCT GAC TTG CAC-3') primers. Each tube contained sterile 
mili-Q $\mathrm{H}_{2} \mathrm{O}(50 \mu \mathrm{L}) ; 10 \mathrm{X}$ “PCR Buffer” (5 $\left.\mu \mathrm{L}\right)$ (Gibco-BRL); 10 $\mathrm{mM}$ "dNTP mixture" (1 $\mu \mathrm{L})$ (Gibco-BRL); $50 \mathrm{mM} \mathrm{MgCl}_{2}(1.5 \mu \mathrm{L})$ (Gibco-BRL); DNA ( $1 \mu \mathrm{L})$; Taq-DNA polymerase $(5 \mathrm{U})(0.25 \mu \mathrm{L})$ (Gibco-BRL), and $11 \mu \mathrm{g} / \mathrm{mLRR} 2$ primer or $8.25 \mu \mathrm{g} / \mathrm{mL} 434$ primer. Tubes were cycled through denaturation at $94^{\circ} \mathrm{C}$, annealing at $30^{\circ} \mathrm{C}$, and extension at $72^{\circ} \mathrm{C}$. Each step lasted $5 \mathrm{~min}$. in the case of the first 4 cycles. Denaturation and annealing were shortened to $1 \mathrm{~min}$., and extension to $2 \mathrm{~min}$. for 35 more cycles, ending with a final extension step of $5 \mathrm{~min}$.

The RAPD assay was accomplished as described by Williams et al. (43), with the OPR2 (5'CACAGCTGCC3'), OPR8 (5'CCCGTTGCCT3'), and OPR13 (5'GGACGACAAG3') primers. Each tube contained sterile mili- $\mathrm{QH}_{2} \mathrm{O}(50 \mu \mathrm{L}) ; 10 \mathrm{X}$ "PCR Buffer" $(5 \mu \mathrm{L})$ (Gibco-BRL); $10 \mathrm{mM}$ “dNTP mixture" (1 $\mu \mathrm{L})$ (Gibco-BRL); $50 \mathrm{mM} \mathrm{MgCl} 2(1.5 \mu \mathrm{L})$ (Gibco-BRL); DNA (1 $\mu \mathrm{L})$; Taq-DNA polymerase ( $5 \mathrm{U})(0.25 \mu \mathrm{L})$ (Gibco-BRL) and one of the primers $(1 \mu \mathrm{L})$. The tubes containing either OPR 2 or 8 were cycled through denaturation at $94^{\circ} \mathrm{C}$, annealing at $33^{\circ} \mathrm{C}$, and extension at $72^{\circ} \mathrm{C}$. Each step lasted $1 \mathrm{~min}$., for 45 cycles. The tubes with OPR 13 were cycled through denaturation at $94^{\circ} \mathrm{C}$, annealing at $30^{\circ} \mathrm{C}$, and extension at $72^{\circ} \mathrm{C}$. The two first steps lasted $1 \mathrm{~min}$. and the last step lasted $2 \mathrm{~min}$., for 45 cycles.

All primers were purchased from Operon Technologies and the reactions were run in an MJ Research Thermo Cycler.

\section{AP-PCR fingerprinting analyses}

The AP-PCR fingerprinting analysis of the amplified DNA fragments obtained after agarose gel electrophoresis was recorded. The presence of a given band was coded as 1 and the absence of a given band was coded as 0 in a data matrix, analyzed using the Program NTSYSpc, version $2.10 \mathrm{~m}$ (Copyright c 1986-2000 Appied Biostatistics Inc.). Similarity dendrograms containing all the isolates were built.

\section{Transmission Electron Microscopy (TEM) studies}

TEM studies were carried out in order to visualize the fibril structures. These studies were performed as described by Handley et al. (13) in a 906 Carl Zeiss electron microscope. The strains were grown overnight at $37^{\circ} \mathrm{C}$ in a brain heart infusion broth. The cells were harvested and washed three times in a saline 3\% - sucrose $1 \%$ solution, and then negatively stained in uranyl acetate $2 \%$, according to Handley et al. (13).

\section{Adhesion to in vitro cultivated HEp-2 and KB cells and to oral epithelial cells}

Adhesion to in vitro cultivated HEp-2 (human larynx epithelial cells) (ATCC HB-8065) and KB (derived from human oral epithelial carcinoma) (ATCC CCL-17) cells was accomplished as described by Scaletsky et al. (35). Adhesion to oral epithelial cells was carried out as described by St. Geme and Cutter (41). The in vitro adhesion model was performed to investigate the interaction of $S$. crista with KB, HEp-2, and epithelial cells, which, to the best of our knowledge, has not been reported in previous studies. Results concerning adhesion to all cells were observed under light microscope with magnification of 1,000X. The strains EPEC 2348/69 and Escherichia coli $\mathrm{K} 12 \mathrm{HB} 101$ were used as control strains for the adhesion studies with HEp-2 cells, and E. coli K12 HB101 and Porphyromonas gingivalis ATCC 33277 were used as control in the case of KB cells.

\section{Co-aggregation tests}

The co-aggregation tests were performed as described by Cisar et al. (5), with the modifications suggested by Handley et al. (12), to determine the aggregation model exhibited by the studied bacteria. F. nucleatum ATCC 10953 was anaerobically grown in brain heart infusion broth (Difco) at $37^{\circ} \mathrm{C}$, for 5 days. S. crista strains were grown on a complex medium containing $0.5 \%$ tryptone, $0.5 \%$ yeast extract, and $0.05 \%$ Tween 80 , buffered to $\mathrm{pH} 7.5$ with $\mathrm{K}_{2} \mathrm{HPO}_{4}$. The cultures were harvested by triple washing in co-aggregation buffer $(0.25 \mathrm{M}$ potassium phosphate pH8.0 supplied with $0.025 \mathrm{M}$ sodium chloride and $0.02 \%$ sodium azide). The washed suspensions were adjusted to an optical density of 1.5 at $660 \mathrm{~nm}$. Aliquots $(0.2 \mathrm{~mL})$ of the $S$. cristas and the $F$. nucleatum suspensions were mixed on a rotamixer, left at room temperature for $1 \mathrm{~h}$, mixed again, and flicked gently with the finger a few times before being scored for co-aggregation. Control tubes were set up with co-aggregation buffer $(0.2 \mathrm{~mL})$. The tubes were allowed to stand at room temperature overnight, mixed the next day for at least 10 s, and scored again. Scores for the degree of co-aggregation ranged from "zero" to "four +" rating as follows: 0 - no visible aggregates in suspension; $1+$ small uniform co-aggregates in suspension; $2+-$ definite coaggregates easily seen but suspension remains turbid without immediate settling of co-aggregates; 3+ - large co-aggregates formed with some settling, although the majority remained in suspension; 4+ - large co-aggregates which settle very rapidly leaving a clear supernatant.

\section{RESULTS}

In this work, eight $S$. crista strains (C1 to C8) were isolated from the dental biofilm of twelve women aged between 20 and 40 , and identified by means of the Vitek (bioMerieus) and the BBL Crystal (Becton Dickison) identification kits.

All the isolates presented fibril tufts on the polar extremities of the cells when analyzed by TEM (Fig. 1-a). They also adhered to mouth epithelial cells but not to HEp-2 or KB cells cultivated in vitro (Fig. 1-b). Strains $\mathrm{C} 1$ to $\mathrm{C} 8$ were able to bind to salivary amylase as do the standard strains. Co-aggregation test results are shown in Table 1.

The AP- PCR assay, using the RR2 and 434 primers (Fig. 3 and 4), and the RAPD assays, using the OPR primers, were able to amplify several DNA fragments shown in Table 2. 
Table 1. Co-aggregation level exhibited by the control strains PSH1a, PSH1b, CR3, CR311 and the isolated strains.

\begin{tabular}{lccccccccccccc}
\hline Strain & PSH1a $^{\mathrm{a}}$ & $\mathrm{PSH1b}^{\mathrm{a}}$ & $\mathrm{CR}^{\mathrm{b}}$ & $\mathrm{CR}_{111^{\mathrm{b}}}$ & $\mathrm{CC}^{2} \mathrm{AWT}{ }^{\mathrm{b}}$ & $\mathrm{C1}^{\mathrm{c}}$ & $\mathrm{C}^{\mathrm{c}}$ & $\mathrm{C}^{\mathrm{c}}$ & $\mathrm{C}^{\mathrm{c}}$ & $\mathrm{C}^{\mathrm{c}}$ & $\mathrm{C6}^{\mathrm{c}}$ & $\mathrm{C}^{\mathrm{c}}$ & $\mathrm{C}^{\mathrm{c}}$ \\
\hline Co-aggregation Level & 0 & 0 & 3 & 3 & 2 & 0 & 0 & 0 & 0 & 0 & 3 & 3 & 0 \\
\hline
\end{tabular}

( ${ }^{\mathrm{a} S}$. parasangui strain types, ${ }^{\mathrm{b}} \mathrm{S}$. crista strain types, ${ }^{\mathrm{c}} \mathrm{Clinical}$ isolate).

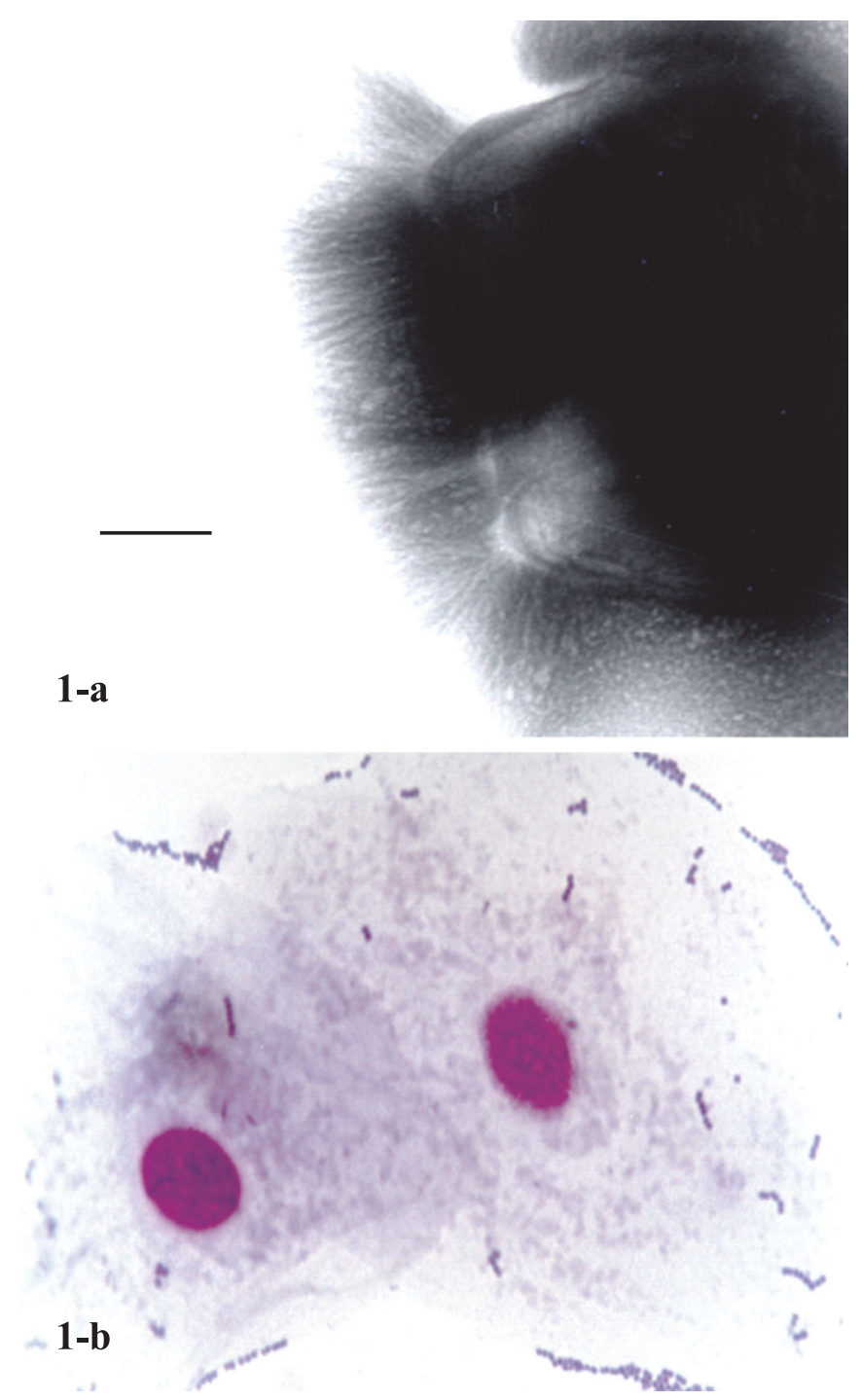

Figure 1. 1-a - C8 strain negatively stained, showing lateral tufts of fibrils on one side of each cell. The cells are in division process. Bar $=92 \mathrm{~nm} .1$-b - Adherent strain $\mathrm{C} 1$ in scraped oral cells. Magnification: $1000 \mathrm{X}$.

Analysis of the above data allowed us to build different similarity dendrograms. The similarity dendrogram obtained by using data from the RR2 and 434 primers (Fig.2-a) indicated $100 \%$ similarity between strains CR 311 and C1 (fingerprinting
1); $\mathrm{C} 3, \mathrm{C} 4$, and $\mathrm{C} 5$ (fingerprinting 2); $\mathrm{C} 7$ and $\mathrm{C} 8$ (fingerprinting 3). Strain CR 3 had $98 \%$ similarity with fingerprinting 1 and strain C2 displayed $97 \%$ similarity with fingerprinting 2 . Concerning these three major fingerprintings, there was $94 \%$ similarity between fingerprintings 1 and 2; 39\% among fingerprintings 3 and 1 and 2. Strain C6 had closer similarity (56\%) with fingerprintings 1 and 2 than with fingerprinting 3 (39\%). By using these primers, all strains exhibited only $22 \%$ similarity with the standard strain CC5AWT.

The dendrogram obtained by using the OPRs and RR2 and 434 primers together (Fig.2-b) showed a similar pattern, but with a different strain distribution. In this way, strains CR311 and C1 were identical, and strains $\mathrm{CR} 3, \mathrm{C} 4, \mathrm{C} 5$, and $\mathrm{C} 2$ had a high degree of similarity. The same was observed for strains C7 and C8. Strain C3, which was considered to have a high degree of similarity (100\%) with strains C4 and C5 and a high degree of similarity with strain $\mathrm{C} 2$ when the RR2 and 434 primers were used (Fig.2-a), was then considered to have a smaller degree of similarity (56\%) (Fig.2-b). All strains had only 24\% similarity with the control CC5AWT.

\section{DISCUSSION}

The purpose of this work was to biologically characterize different $S$. crista strains obtained from the dental biofilm of different adult individuals seen at the Dental Clinic of São Francisco University, Bragança Paulista, SP, Brazil by means of molecular techniques, and to compare the results with those published by other groups $(3,6,7-9,13,18,19,32,44)$. To the best of our knowledge, no other research group has published in Brazil, any characterization of these types of strains regarding their molecular profile.

Salivary amylase assays were carried out to differentiate $S$. crista from other Streptococcus groups, once the amylasebinding capacity is specific to some oral Stretpcocci (9). The results obtained by other authors $(9,13,44)$ and us showed that all the $S$. crista strains have the ability to bind to salivary amylase. This enzyme is one of the major components of the acquired pellicle, and the amylase-binding streptococci are the predominant amylase-binding bacteria $(\mathrm{ABB})$ in the human biofilm (reviewed by 14,38). Besides helping in the identification, these data could suggest that the ability to bind to amylase may play an important role in the oral colonization by streptococci. 
Table 2. Fragment size (bp) of the amplicons obtained by using the OPR2, OPR8, OPR13, RR2, and 434 primers

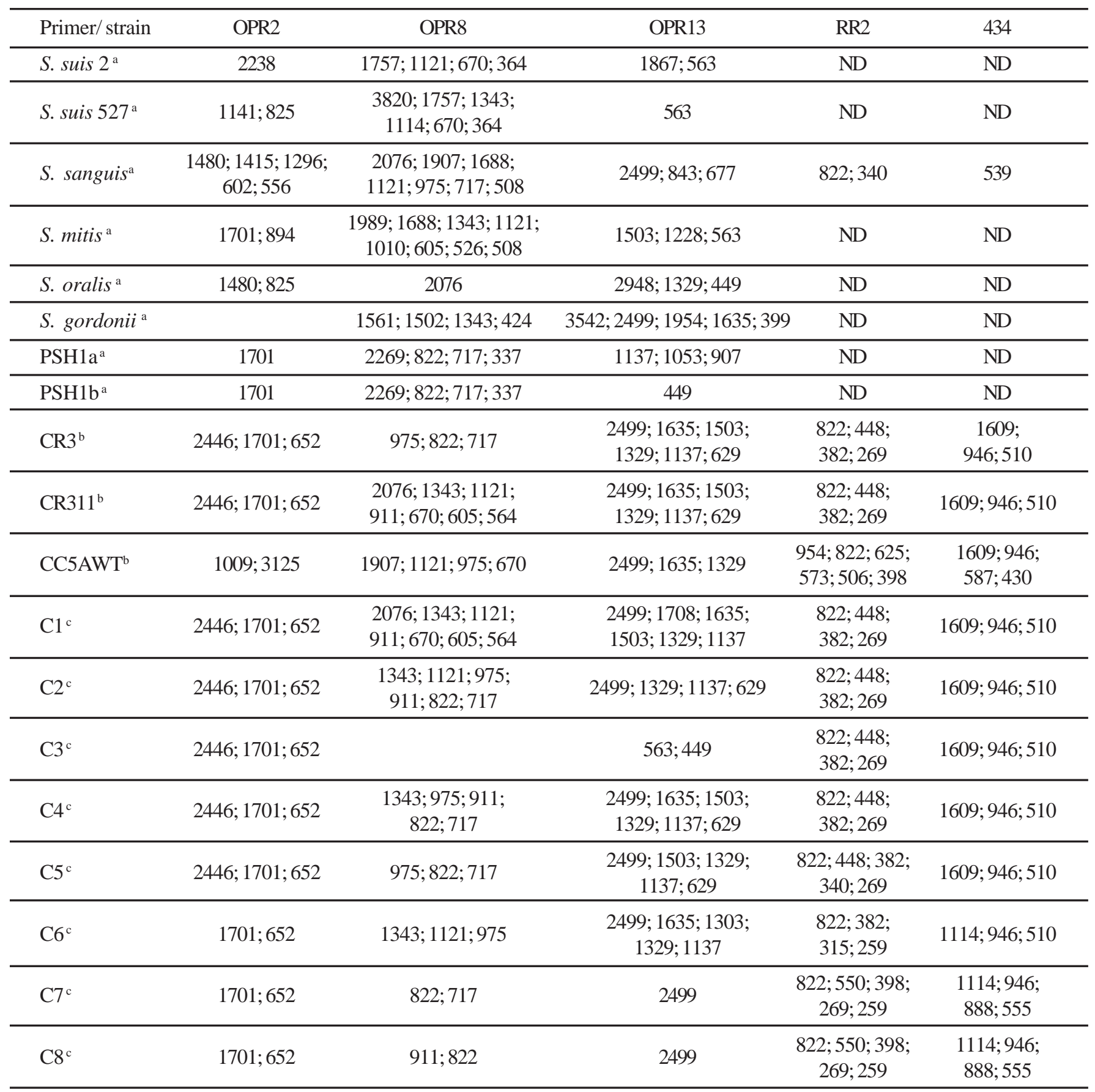

( ${ }^{\mathrm{a}}$ Streptococcus strain types; ${ }^{\mathrm{b}} \mathrm{S}$. crista strain types; ${ }^{\mathrm{c} C l i n i c a l}$ isolate, ND not determined).

To the best of our knowledge, the adhesion assays accomplished in this work have not been used with $S$. crista before. These assays were carried out by us because, if positive, they could suggest the presence of adhesion in the strains. Our results were positive for adhesion in the case of mouth epithelial cells only, but not in the case of HEp-2 or KB cells. This suggests that mouth epithelial cells could be used in adhesion assays to study the possible in vivo interaction 


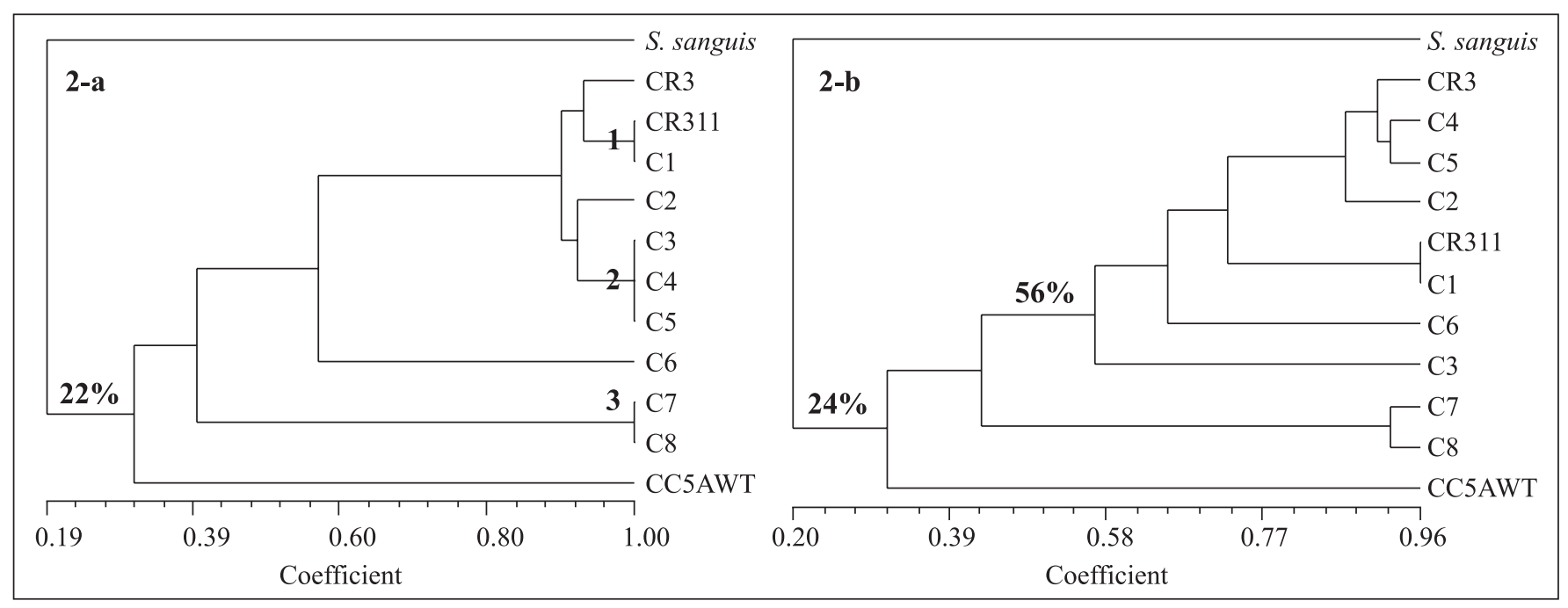

Figure 2. Dendrograms obtained from the AP-PCR analysis. 2-a- Dendrogram obtained by using the RR2 and 434 primers. 2-b- Dendrogram obtained by using primers RR2, 434, OPR2, OPR8, and OPR13.

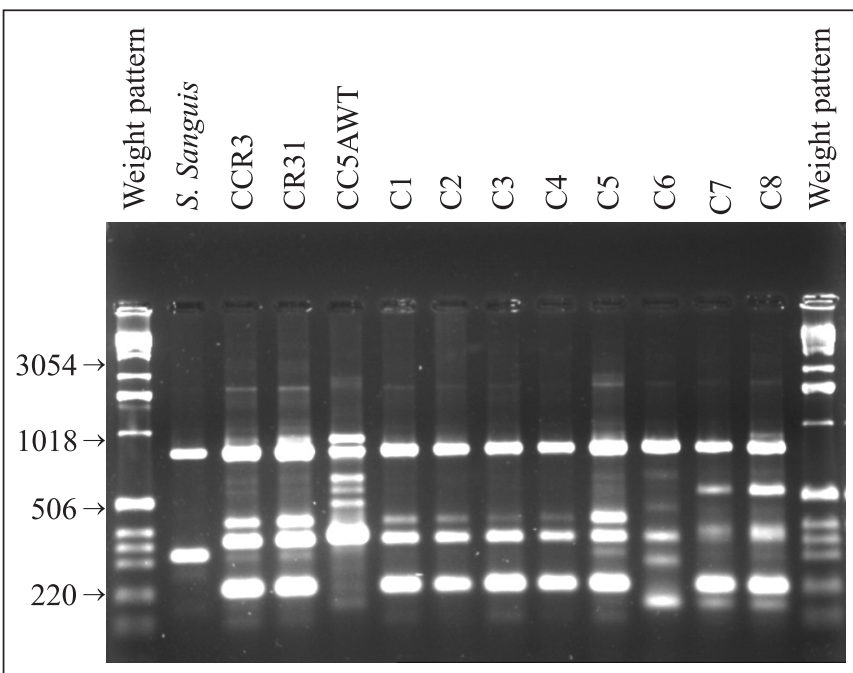

Figure 3. Agarose gel (2\%) showing the amplicon patterns obtained with the RR2 primer.

of $S$. crista with the mouth and dental environments. The negative results obtained for the other cells could be explained either by the absence of adhesin receptors possibily expressed by this bacterium species or by the fact that the way they were cultivated is not the most appropriate for the expression of these receptors.

Therefore, because salivary amylase and mouth cells are components of the acquired pellicle, it could be suggested that adherence and amylase-binding are mechanisms used by $S$. crista for biofilm formation. As shown in other works

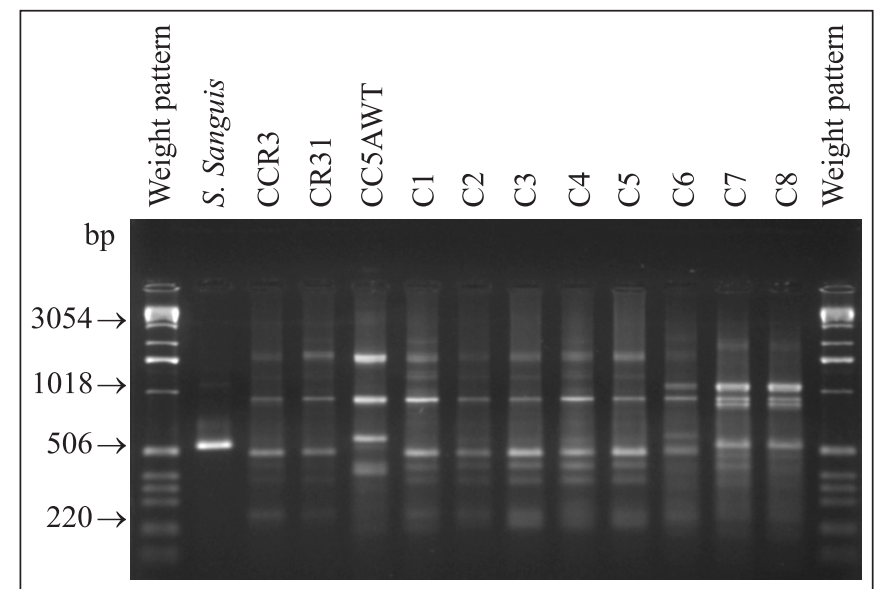

Figure 4. Agarose gel (2\%) showing the amplicon patterns obtained with the 434 primer.

$(11,39,47)$, the biofilm helps cell-cell communication, which is important in the formation and development of the oral bacterial community composed by $S$. crista and other oral pathogens, as suggested by Xie et al. (46). However, the exact role of $S$. crista has not been fully elucidated yet.

Complete biolfilm formation involves co-aggregation among the individuals of the bacterial community $(20,24,25)$. Coaggregation occurs via formation of corncob structures among S. crista, C. matrychotti, and $F$. nucleatum $(6,7,12,13)$. The presence of corncob structures is a biological characteristic of S. crista strains and it is believed that their presence is related to the presence of the fibril tuft (13). 
Our results demonstrated that only the S. crista control strains and the $\mathrm{C} 6$ and $\mathrm{C} 7$ strains have the ability to co-aggregate with $F$. nucleatum, despite the fact that all the strains presented fibril tufts when analyzed by TEM. These results indicate that the fibril tuft present in the S. crista strains cannot to be responsible for the adhesion capacity observed in the corncob structures and they show that afibrillar adhesins could be present in this bacteria, as already observed for other bacterial strains $(21,40,48)$.

Rudney and Larson (32) proposed the use of amplified DNA fragments with the RR2 (822bp and 316bp) and 434 (964bp and 729bp) primers to characterize $S$. crista strains and to differentiate them from other Streptococcus strains found in the mouth.

Our results using both primers described by Rudney and Larson (32), and also both primers together with additional primers (OPRs), indicated a varied degree of similarity among the $S$. crista strains studied herein. The results using the latter method (combination of primers) showed a lower similarity among strains than that obtained when only the RR2 and 434 primers were used.

In this way, although the amplified fragments were not the same as those described by Rudney and Larson (32), we believe that the fragments obtained by us when using the same primers could reflect regional differences among strains. We also believe that the set of primers described herein could be used to better characterize and discriminate S. crista from other Streptococcus strains. It is also noteworthy that the strains studied herein bear higher similarity with strains from the United Kingdom (CR3 and CR311) than with the one that is considered to be a standard (CC5AWT)(USA). Although we have not studied strains from other Brazilian regions, which could give us different results from those obtained herein and could therefore present a more similar profile to that of CC5AWT, our results could be explained by means of a possibly founder principle occurring in an original strain, which is more likely to be very similar to or identical to strains CR3/CR311 followed by random mutations (26).

Furthermore, the electron microscope and adhesion assays accomplished herein indicated that other not yet described adhesins could be present in certain S. crista strains. These adhesins could participate in the adhesion processes present in these strains, being thus involved in the biofilm formation. Studies are presently underway in our laboratory aiming at characterizing these possible adhesins.

\section{ACKNOWLEDGMENTS}

This work was supported by grant $n^{\circ} 99 / 05270-7$ from the São Paulo State Research Foundation (FAPESP) and by a grant from the National Council for Scientific and Technological Development (CNPq).

\section{RESUMO}

\section{Caracterização biológica e molecular de linhagens de Streptococcus crista isoladas do biofilme dental de seres humanos através de iniciadores arbitrários - PCR (AP-PCR)}

Streptococcus spp são importantes componentes do biofilme dental sendo Streptococus crista considerado um interessante modelo de interações bacterianas que nele ocorrem. No presente trabalho linhagens de $S$. crista, foram isoladas do biofilme dental de indivíduos brasileiros, e estudadas em relação a suas características biológicas e ao seu perfil molecular através da técnica do AP-PCR, usando-se os iniciadores RR2, 434, OPR2, OPR8 e OPR13. Os resultados nos permitiram construir um dendrograma de similaridade. A análise do dendrograma de similaridade permitiu a separação das linhagens estudadas em grupos de similaridade. Todos os isolados apresentaram tufo de fibrilas, quando estudados por Microscopia Eletrônica de Transmissão (MET). Estes isolados foram capazes de se ligar à amilase salivar e de se aderir a células epiteliais bucais. Algumas linhagens, que apresentam tufo de fibrilas e aderência positiva, não foram capazes de coagregar com a Fusobacterium nucleatum, sugerindo que diferentes grupos de adesinas estão presentes nestas amostras.

Palavras-chave: caracterização biológica, caracterização molecular, análise de dendrograma, biofilme

\section{REFERENCES}

1. Ausubel, F.M.; Brent, R.; Kingston, R.E.; Moore, D.D.; Smith, J.A.; Seidman, J.G.; Struhl, K. Curr. Prot. Mol. Biol. Green Publishing Associates, Brooklyn, N.Y, 1988.

2. Beighton, D.; Russel, R.R.B.; Hayday, H. The isolation and characterization of Streptococcus mutans serotype h from dental plaque of monkeys (Macaca fascicularis). J. Gen. Microbiol., 124(2), 271-279, 1981.

3. Beighton, D.; Hardie, J.M.; Whiley, R.A. A scheme for the identification of viridans streptococci. J. Med. Microbiol., 35(6), 367-372, 1991

4. Cassels, F.J.; Hughes, C.V.; Nauss, J.L. Adhesin receptors of human oral bacteria and modeling of putative adhesin-binding domains. $J$. Ind. Microbiol., 15(3), 176-185, 1995.

5. Cisar, J.O.; Kolenbrander, P.E.; McIntire, F.C. Specificity of coagregation reactions between human oral streptococci and strains of Actinomyces viscosus or Actinomyces naeslundii. Infect. Immun. 24(3), 742-752, 1979.

6. Correia, F.F.; DiRienzo, J.M.; Lamont, R.J.; Anderman, C.; McKay, T.L.; Rosan, B. Insertional inactivation of binding determinants of Streptococcus crista CC5A using Tn916. Oral Microbiol. Immunol., 10(4), 220-226, 1995.

7. Correia, F.F.; DiRienzo, J.M; McKay, T.L.; Rosan, B. scbA from Streptococcus crista CC5A: an atypical member of the Ira I gene family. Infect. Immun., 64(6), 2114-2121, 1996.

8. Cvitkovitch, D.G.; Hamilton, I.R. Biochemical change exhibited by oral streptococci resulting from laboratory subculturing. Oral Microbiol. Immunol., 9(4), 209-217, 1994. 
9. Douglas, C.W.I.; Pease, A.A.; Whiley, R.A. Amylase - binding as a discriminator among oral streptococci. FEMS Microbiol. Lett., 54(13), 193-197, 1990.

10. Facklam, R. What happened to the Streptococci: overview of taxonomic and nomenclature changes. Clin. Microbiol. Rev., 15(4), 613-630, 2002.

11. Gibbons, R.J.; Hay, D.I.; Schlesinger, D.H. Delineation of a segment of adsorbed salivary acidic proline-rich proteins which promotes adhesion of Streptococcus gordonii to apatitic surfaces. Infect. Immun., 59, 2948-2954, 1991.

12. Handley, P.S.; Carter, P.L.; Wyatt, J.E.; Hesketh, L.M. Surface structure (peritrichous fibrils and tufts of fibrils) found on Streptococcus sanguis strains may be related to their ability to coaggregate with other oral genera. Infect. Immun., 47(1), $217-$ 227, 1985.

13. Handley, P.; Coykendall, A.; Beighton, D.; Hardie, J.M.; Whiley, R.A. Streptococcus crista sp. nov., a viridans Streptococcus with tufted fibrils, isolated from the human oral cavity and throat. Int. J. Syst. Bacteriol., 41(4), 543-547, 1991.

14. Hanning, C.; Hanning, M.; Attin, T. Enzymes in the acquired enamel pellicle. Eur. J. Oral. Sci., 113(1), 2-13, 2005.

15. Homer, K.A.; Roberts, G.; Byers, H.L.; Tarelli, E.; Whiley, R.A.; Philpott-Howard, J.; Beighton, D. Manosidase production by viridans group Streptococci. J. Clin. Microbiol., 39(3), 995-1001, 2001.

16. Jenkinson, H.F. Genetic analisis of adherence by oral streptococci. J. Ind. Microbiol., 15(3), 186-192, 1995.

17. Kawamura, Y.; Hou, X.G.; Sultana, F.; Miura, H.; Ezaki, T. Determination of 16S rRNA sequences of Streptococcus mitis and Streptococcus gordonii and pHylogenetic relationships among members of the genus Streptococcus. Int. J. Syst. Bacteriol., 45(2), 406-408, 1995.

18. Kikuchi, K.; Enari, T.; Totsuka, K.; Shimizu, K. Comparison of phenotypic characteristics, DNA-DNA hibridization results, with a commercial rapid biochemical and enzymatic reaction system for identification of viridans group streptococci. J. Clin. Microbiol., 33(5), 1215-1222, 1995.

19. Kilian, M.; Nyvad, B. Ability to bind salivary a-amylase discriminates certain viridans streptococcal species. J. Clin. Microbiol., 28(11), 2576-2577, 1990.

20. Kolenbrander, P.E.; Andersen, R.N.; Kazmerak, K.M.; Palmer, R.J. Coaggregation and coadhesion in oral biofilms. In: Community Structure and Co-Operation in Biofilms. Allison, D.G.; Gibert, P.; Lappin-Scott, H. M.; Wilson, M. (eds). Society for General Microbiology Symposium 59. Cambridge, Cambridge University Press, 2000, p.65.

21. Lalioui, L.; Jouve, M.; Gounon, P.; Le Bouguenec, C. Molecular clonning and characterization of the afa- 7 and afa- 8 gene clusters encoding afimbrial adhesins in Escherichia coli strains associated whith darrhea or septicemia in calves. Infect. Immun., 67(10), 50485059, 1999.

22. Lancy Jr., P.; Appelbaum, B.; Holt, S.C.; Rosan, B. Quantitative in vitro assay for "corncob" formation. Infect. Immun., 29(2), 663$670,1980$.

23. Lancy Jr., P.; Dirienzo, J.M.; Appelbaum, B.; Rosan, B.; Holt, S.C. Corncob formation between Fusobacterium nucleatum and Streptococcus sanguis. Infect. Immun., 40(1), 303-309, 1983.

24. Listgarten, M.A. Formation of dental plaque and other oral biofilms. In: Newman, H. N.; Wilson, M. (eds). Dental plaque revisited: oral biofilms in health and disease. Bioline, Cardiff, Wales, 1999, p.187210 .

25. Marsh, P.D. Dental plaque as a microbial biofilm. Caries Res., 38(3), 204-211, 2004

26. Mayr, E. Animal species and evolution. Harvard University Press, Cambridge, Massachusetts, 1963, 529p.
27. Menard, C.; Mouton, C. Randomly amplified polymorpHic DNA analysis confirms the biotyping scheme of PorpHyromonas gingivalis. Res. Microbiol., 144(6), 445-455, 1993.

28. Mouton, C.; Reynolds, H.S.; Genco, R.J. Characterization of tufted streptococci isolated from the "corncob" configuration of human dental plaque. Infect. Immun., 27(1), 235-245, 1980.

29. Perea, E.J. Oral flora in the age of molecular biology. Med. Oral Patol. Oral Cir. Bucal, 9(6), 1-5, 2004.

30. Rudney, J.D.; Larson, C.J. Species identification of oral viridans streptococci by restriction fragment polymorpHism analysis of rRNA genes. J. Clin. Microbiol., 31(9), 2467-2473, 1993.

31. Rudney, J.D.; Larson, C.J. Use of restriction fragment polymorpHism analysis of rRNA genes to assign species to unknown clinical isolates of oral viridans streptococci. J. Clin. Microbiol., 32(2), 437-443, 1994.

32. Rudney, J.D.; Larson C.J. Identification of oral mitis group streptococci by arbitrarily primed polymerase chain reaction. Oral Microbiol. Immunol., 14, 33-42, 1999.

33. Rudney, J.D. Saliva and dental plaque. Adv. Dent. Res., 14, 29-39, 2000.

34. Sambrook, J.; Fritsh, E.F.; Maniatis, T. Molecular cloning: A Laboratory Manual. Cold Spring Harbor Laboratory Press, Cold Spring Harbor, New York, 1989, 3 (E5).

35. Scaletsky, I.C.A; Milani, S.R; Trabulsi, L.R.; Travassos, L.R. Isolation and characterization of the localized adherence factor of enteropathogenic Escherichia coli. Infect. Immun., 56(11), 29792983,1988

36. Sbordone, L.; Bortolaia, C. Oral microbial biofilms and plaque-related diseases: microbial communities and their role in the shift from oral health to disease. Clin. Oral Invest., 7(4), 181-188, 2003.

37. Scannapieco, F.A.; Bergey, E.J.; Reddy, M.S.; Levine, M.J. Characterization of salivary a-amylase binding to Streptococcus sanguis. Infect. Immun., 57(9), 2853-2863, 1989.

38. Scannapieco, F.A.; Solomon, L.; Wadenya, R.O. Emergence in human dental plaque and host distribuition of amylase-binding Streptococci. J. Dent. Res., 73(10), 1627-1635, 1994.

39. Scannapieco, F.A.; Torres, G.I.; Levine, M.J. Salivary amylase promotes adhesion of oral streptococci to hydroxyapatite. J. Dent. Res., 74(7), 1360-1366, 1995.

40. Sherlock, O; Vejborg, R.; Klemm. P. The TibA adhesin/invasin from enterotoxigenic Escherichia coli self recognizing and induces bacterial aggregation and biofilm formation. Infect. Immun., 73(4), 19541963, 2005.

41. St. Geme III, J.W.; Cutter, D. Influence of pili and capsule on in vitro adherence by HaemopHilus influenzae type b. Mol. Microbiol., 21(1), 21-31, 1996.

42. Tran, S.D.; Rudney, J.D. Multiplex PCR using conserved and speciesspecific 16s rRNA gene primers for simultaneous detection of Actinobacillus actinomycetemcomitans and PorpHyromonas gingivalis. J. Clin. Microbiol., 34 (11), 2674-2678, 1996.

43. Williams, J.G.; Kubelik, A.R.; Livak, K.J.; Rafalsk, J.A.; Tingly, S.V. DNA polymorphisms amplified by arbitrary primers are useful as genetic markers. Nucleic Acids Res., 18(22), 6531-6535, 1990.

44. Willcox, M.D.P. Identification and classification of species within the Streptococcus sanguis group. Aust. Dent J., 41, 107-112, 1996.

45. Xie, H.; Cook, G.S.; Costerton, J.W.; Bruce, G.; Rose, T.M.; Lamont, R.J. Intergeneric communication in dental plaque biofilms. $J$. Bacteriol., 182(24), 7067-7069, 2000.

46. Xie, H; Kozlova, N.; Lamont, R.J. Porphyromonas gingivalis genes involved in fimA regulation. Infect. Immun., 72(2), 651-658, 2004.

47. Yao, E.S.; Lamont, R.J.; Leu, S.P.; Weinberg, A. Interbacterial binding among strains of pathogenic and commensal oral bacterial species. Oral Microbiol. Immunol, 11(1), 35-41, 1996.

48. Zhang, Y.; Lei, Y.; Nobbs, A.; Khammanivong, A.; Herzberg, M.C. Inactivation of Streptococcus gordonii $\mathrm{SspAB}$ alters expression of multiple adhesin genes. Infect. Immun, 73(6), 3351-3357, 2005. 